\title{
An unusual cause of late tracheostomy bleed
}

\author{
V. Hemanth ${ }^{1^{*}}$, C. Satish Kumar ${ }^{1}$, D. Manikandan ${ }^{1}$, F. Musarrat ${ }^{2}$, A. P. Preetham ${ }^{2}$, M. G. Paulraj ${ }^{3}$ \\ ${ }^{1}$ Department of Otorhinolaryngology, Southern Railway Headquarters Hospital, Chennai, India; \\ *Corresponding Author: vhemanth2000@yahoo.com \\ ${ }^{2}$ Department of Otorhinolaryngology, Southern Railway Headquarters Hospital, Chennai, India \\ ${ }^{3}$ Entomology Research Institute, Loyola College, Chennai, India
}

Received 23 April 2013; revised 23 May 2013; accepted 15 June 2013

Copyright (c) 2013 V. Hemanth et al. This is an open access article distributed under the Creative Commons Attribution License, which permits unrestricted use, distribution, and reproduction in any medium, provided the original work is properly cited.

\begin{abstract}
Human myiasis is common in the tropical and subtropical areas of the world. Tracheostomal myiasis is a rare entity, and only 7 such cases have been reported in literature. Our study emphasizes the importance of health education with regards to hygiene, sanitation and home tracheostomy tube care especially in immunocompromised individuals.
\end{abstract}

Keywords: Tracheostomy Bleed; Myiasis; Chrysomya Bezziana

\section{INTRODUCTION}

The term myiasis is derived from the Greek "muia" fly, and is defined as "a parasitic infestation of live human or vertebrate animal tissues or cavities caused by dipterous larvae (maggots) which feed on host's dead or living tissue, liquid body substances or ingested food" [1]. Myiasis has been described as "God's punishment for sinners" in Hindu mythology [1,2].

Human myiasis is common in the tropical and subtropical areas of the world. The commonly implicated dipterous families are Muscidae, Sarcophagidae, Calliphoridae, Anisopodidae and Scinoinidae [3]. Myiasis related to tracheostomy is a rarity and only 7 such cases have been reported in literature.

We report an unusual case of late tracheostomy bleed caused due to infestation of maggots around the tracheostoma with a review of relevant literature.

\section{CASE REPORT}

A 73-year-old diabetic patient, a known case of carcinoma supraglottis, presented to the Emergency department of Southern Railway Headquarters Hospital, Chennai, with complaints of painless bleeding from the tracheostomal site. The patient had undergone tracheo- stomy in our hospital 1 year ago for stridor. On evaluation he was found to have carcinoma of the supraglottis (stage III) with fixity of the left hemilarynx. He had since then received concurrent Chemo-radiotherapy for his cancer and was on a monthly follow up at our hospital.

On examination, patient was on an uncuffed Shiley's tracheostomy tube. Serosanguinous discharge was noted from the tracheostoma site. On lifting the flange of the Shiley's tube, a pus filled ulcerative wound was seen, infested with maggots. The surrounding tissue was tense, oedematous and emitting a foul odour.

The wound was cleaned and mopped with gauze soaked in ether. The maggots were then manually picked out with the tracheostomy tube in situ. Since the patient was on an uncuffed tube, wound irrigation could not be done, hence the tube was removed. The wound cavity re-inspected and the visualized maggots were removed (Figure 1(A)). A cuffed Portex tracheostomy tube was inserted into the stoma. The wound was irrigated with a mixture of Betadine and Hydrogen peroxide solutions. A total of 116 maggots were removed on day 1.

In the next three days, 14 maggots were removed (Total of 130 maggots). Daily dressings with Ether instillation followed by a mixture of Betadine and Hydrogen peroxide were done, with the Portex Tracheostomy tube's cuff inflated. On the third day after presentation, no maggots were found around the treacheostomal site. Daily dressings were however continued till day 7 (Figure 1(B)). Patient was then discharged on a Shiley's No. 6 size Tracheostomy tube.

Six live maggots were then sent to the Entomology Research Institute at Loyola College, Chennai for species identification. The larvae were reared at laboratory conditions $\left(26^{\circ} \mathrm{C} \pm 11^{\circ} \mathrm{C} ; 70 \%\right.$ - $75 \%$ relative humidity; $11 \pm$ $0.5 \mathrm{hr}$ photoperiod) (Figure 2(A)). The larvae were examined under stereo microscope and their morphological features were studied and photographed (Figure 3). The 


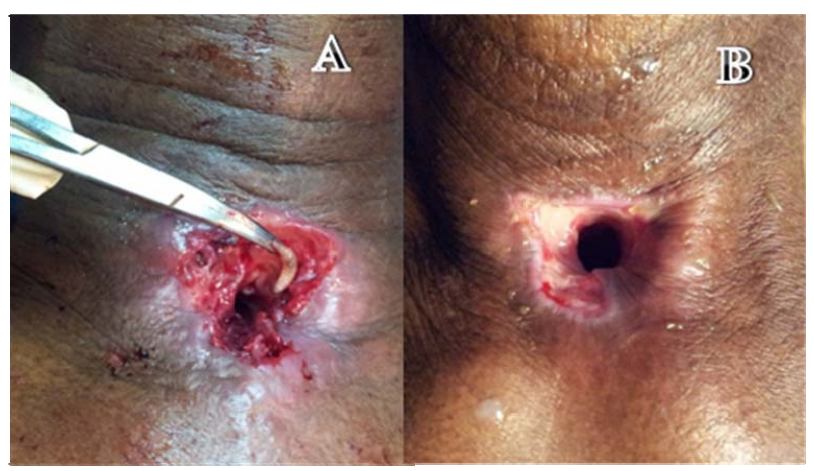

Figure 1. (A) Tracheostomal area on day 1 of presentation, with maggot being removed; (B) Tracheostoma on day 7: healed and epithelised.
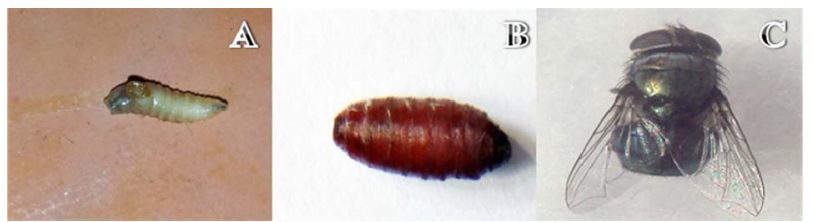

Figure 2. (A) Larva; (B) Pupa; (C) Adult fly. (Dorsal view) of Chrysomya bezziana.

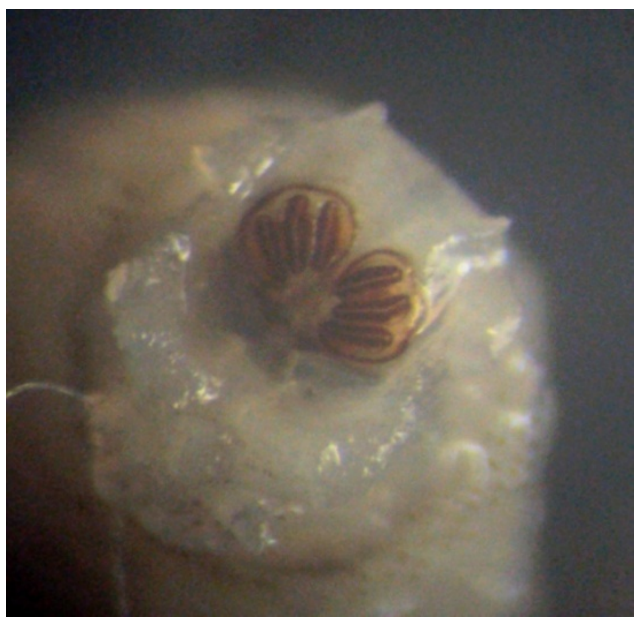

Figure 3. Posterior spiracles in larva (distinguishing feature of Chrysomya bezziana).

larvae pupated within 48 hrs (Figure 2(B)). The pupae were transferred to moist sand taken in petriplates and kept under laboratory conditions. After 8 days of pupal period, two adult flies emerged out. The adult flies were preserved in $80 \%$ ethanol and their morphological features were examined under microscope. The size, colour and morphological structures of head, thorax, abdomen and wings were studied in detail (Figures 2(C) and 4). Based on the thorough examination of the specimen, the flies were identified as the old world screwworm fly Chrysomya bezziana (Villeneuve).

Taxonomy: The maggots belonged to Kingdom: Animalia, Phylum: Arthropoda, Class: Insecta, Order: Dip

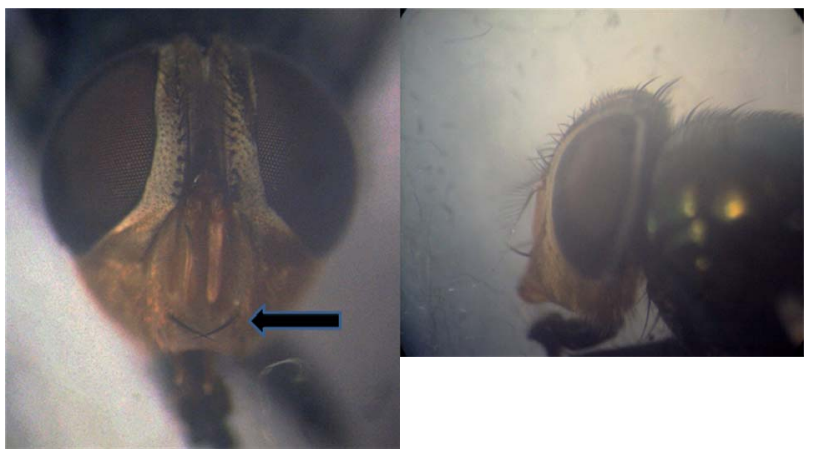

Figure 4. Adult male-frontal and side views. *Arrow shows bristles.

tera, Family: Calliphoridae (Blow Flies), Genus: Chrysomya, Species: bezziana.

\section{DISCUSSION}

The term "myiasis" was coined in 1840 by Rev F. W. Hope (earlier known as scholechiasis). Later in 1919, nasal myiasis caused by chrysomya was reported by Castellani and Chalmer's [2].

Myiasis causing flies can be either Obligate parasites (developing on live hosts only) or Facultative parasites (primarily feeding on cadavers or vegetables, but can infest live tissues sporadically) [1].

Larvae of the Old-world screwworm C. bezziana (Our case) cause Obligatory myiasis among human and animal tissues.

Based on the site of tissue involvement, myiasis can be classified into the following types:

1) Cutaneous and subcutaneous myiasis-invading dermo-epidermal layers.

2) Myiasis of natural cavities-invading nose, oral cavity, ears, pharynx and laryngeal tissues.

3) Myiasis with inner migration-larvae emerge at skin level after migrating from within the body.

Factors predisposing myiasis include immunocompromised states, open wounds with foul smelling discharge, low socioeconomic status, persistent vegetative state, leprosy, close contact with domestic or peridomestic animals like dogs and rats [4].

Our patient was predisposed to myiasis secondary to his diabetic status and poor tracheostomal care.

Very few cases of tracheostomal myiasis have been reported in literature. Two cases were reported in patients who underwent tracheostomy for thyroid malignancy $[3,4]$. One was secondary to foreign body aspiration into the intrathoracic trachea through the tracheostomy tube [5]. Two cases were reported in patients who were in persistent vegetative state $[1,6]$. One case was reported in a patient undergoing Chemotherapy for carcinoma of larynx [7]. The last case reported was in a patient with head injury following road traffic accident who 
failed decanulation twice [8].

\subsection{Pathogenesis}

Attracted by the foul smell of open wounds, the female fly lays its eggs on that part of the wound. On hatching, the larvae penetrate into underlying tissues using their sharp mouth hooks and anchoring inter-segmental spines (Figure 3). Wound healing is prevented by inflammation and toxins secreted by the larvae. The most striking feature among these patients is the characteristic absence of pain or discomfort due to destruction of sensory nerve endings, in spite of bloody discharge [3].

\subsection{Life Cycle}

Larvae attain maturity within 5 - 7 days, after feeding continuously on wounds, following which they exit the wound and drop to the ground. Mature larvae move away from light and burrow 2 to $5 \mathrm{~cm}$ deep in the soil, where they transform into pupae in about 7 days [9]. Their survival at this stage depends on factors like temperature, humidity, food sources, host availability [10].

Once the pupa becomes an adult screwworm, it feeds on fluids in superficial wounds on warm-blooded animals. The female fly, after mating then deposits eggs along the edges of superficial wounds. Larvae emerge in 8 to 12 hours, enter the wound, and begin feeding. On an average, an egg mass from the Old World Screwworm contains about 100 to 250 eggs [11]. Adult males survive for about 14 days; females survive for about 30 days.

\subsection{Treatment}

Treatment involves initial hospital admission, manual removal of maggots with wound debridement and management of comorbidities. Local application of ether, chloroform or turpentine oil can be used to suffocate the larvae and dislodge them from the wound. The larvae are then manually picked out. Single subcutaneous dose of Ivermectin (200 microgram/kg) or doramectin $(200 \mathrm{mi}-$ crogram $/ \mathrm{kg}$ ) have also been used as treatment options [12-14].

Complications of tracheostomal myiasis include airway obstruction, aspiration pneumonitis, damage to blood vessels of neck, embolisation of maggots into the blood vessels causing thrombosis [8].

\section{CONCLUSION}

Tracheostomal myiasis, although rare, emphasizes the importance of health education with regards to hygiene, sanitation and home tracheostomy tube care especially in immunocompromised individuals. Our case highlights the need for a high index of suspicion when a patient presents with a late tracheostomy bleed.

\section{REFERENCES}

[1] Franza, R., Leo, L., Minerva, T. and Sanapo, F. (2006) Myiasis of the tracheostomy wound: Case report. Acta Otorhinolaryngologica Italica, 26, 222-224.

[2] Arora, S., Sharma, J.K., Pippal, S.K., Sethi, Y. and Yadav, A. (2009) Interval study. Brazilian Journal of Otorhinolaryngology, 75, 356-361.

[3] Gopalakrishnan, S., Srinivasan, R., Saxena, S. and Shanmugapriya, J. (2008) Myiasis in different types of carcinoma cases in southern India. Indian Journal of Medical Microbiology, 26, 189-192. doi:10.4103/0255-0857.40542

[4] Vitavasiri, M.D.A., Charoenchasri, M.D.P., Kaewmanee, M.S.S. and Bhaibulaya, M.D.M. (1995) Subdermal myiasis caused by maggots of chrysomyia bezziana. Siriraj Hospital Gazzetee, 47, 419-422.

[5] Fraga, J.C., Pires, A.F., Komlos, M., Takamatu, E.E., Camargo, L.G. and Contelli, F.H.Á. (2003) Bronchoscopic removal of foreign body from airway through tracheotomy or tracheostomy. Jornal de Pediatria, 79, 369-372. doi:10.1590/S0021-75572003000400017

[6] Bhatia, M.L. and Dutta, K. (1965) Myiasis of the tracheostomy wound. Journal of Laryngology and Otology, 79, 907-911. doi:10.1017/S0022215100064549

[7] Batista-da-Silva, J.A., Borja, G.E.M. and Queiroz, M.M.C. (2011) Patient with tracheostomy parasitized in hospital by larvae of the screwworm. Cochliomyia Hominivorax, 11, 1-7.

[8] Prasanna Kumar, S., Ravikumar, A., Somu, L., Vijaya Prabhu, P. and Subbaraj, R.M.S.P. (2011) Tracheostomal myiasis: A case report and review of the literature. Case Reports in Otolaryngology, 2011, Article ID: 303510.

[9] Baumhover, A.H. (1963) Susceptibility of screwworm larvae and prepupae to desiccation. Journal of Economic Entomology, 56, 645-649.

[10] Parman, D.C. (1945) Effect of weather on cochliomyla Americana and a review of methods and economic applications of the study. Journal of Economic Entomology, 53, 1110-1116.

[11] Kettle, D.S. (1981) Medical and veterinary entomology. Wiley-Interscience, New York, 241-261.

[12] Perkins, I.D. (1987) Use of insecticides to control screwworm fly strike by chrysomya bezziana in cattle. Australian Veterinary Journal, 64, 17-20. doi:10.1111/j.1751-0813.1987.tb06050.x

[13] Spradbery, J.P., Tozer, R.S., Drewett, N. and Lindsey, M.J. (1985) The efficacy of ivermectin against larvae of the screw-worm fly (chrysomya bezziana). Australian Veterinary Journal, 62, 311-314. doi:10.1111/j.1751-0813.1985.tb14913.x

[14] Guimaraes, J.H. and Papavero, N. (1999) Myiasis in man and animals in the neotropical region: Bibliographic database. Pleiade/FAPESP, Sao Paulo. 